\title{
Pigment Variant of Neuronal Ceroid-Lipofuscinosis (Kufs' Disease)
}

\author{
DIKRAN S. HOROUPIAN AND R. T ROSS
}

SUMMARY: A case of pigment variant of Kufs' disease is presented. The nature of the extra-neuronal pigment is discussed. Despite some of the histochemical discrepancies that existed between this pigment and the material that had accumulated in the nerve cells, they seemed to be ultrastructurally related. The hepatocytes contained numerous heterogeneous cytosomes, some of which resembled the storage material of Niemann-Pick's disease.

Clinically the syndrome may present with progressive ataxia, spontaneous and reflex, coarse myoclonic jerks and eventual mental deterioration as well as epilepsy and muscle wasting. The pigment variant cannot be distinguished from Kufs' disease except pathologically.

RÉSUMÉ: Un cas de variante pigmentaire de la maladie de Kuf est présenté. La nature du pigment extraneuronal est discutée. Malgré quelques différences histochimiques ce pigment et le materiel qui était accumulé dans les cellules nerveuse semblaient être relies ultrastructurellement. Les hépatocytes contenaient un grand nombre de cytosomes hétérogènes, dont quelques-uns ressemblaient au matériel de surcharge de la maladie de Niemann-Pick.

Cliniquement, le syndrome peut présenter une ataxie progressive, des sursauts grossiers myocloniques spontanés et réflexes, et une détérioration mentale ainsi que de l'épilepsie qui ne peut être differentie de la maladie de Kufs sans morphologiquement.

From the Departments of Pathology and Medicine, Health Sciences Centre and Faculty of Medicine, University of Manitoba, Winnipeg, Canada.

Part of this work was supported by grant No. MA-4958 from the Medical Research Council of Canada.

Reprint requests: Dr. D. S. Horoupian, Dept. of Pathology, Rose F Kennedy Center, Albert Einstein College of Medicine, 1300 Morris Park Avenue, Bronx, N.Y 10461.

\section{INTRODUCTION}

Pigment 'variant' of Kufs' disease was the term proposed by Seitelberger and Simma (1962) to denote a rare form of cerebral lipidosis as sociated with extraneuronal deposits of pigment. The pigmentary changes resembled Hallervorden-Spatz disease in that the zona reticulata of the substantia nigra and the pallida were heavily pigmented. Some of the cases were confused with Hallervorden-Spatz disease (Simma, 1957). In all cases of pigment 'variant' of Kufs' disease (Jervis, 1970), distended neurons or the so-called Schaffer-Spielmeyer processes, diagnostic of neuronal lipid storage disease, were present. The case presented here failed to display any of these features and the diagnosis was only suggested when the brain and liver biopsies were studied ultrastructurally.

\section{Case Report}

Miss D. L., a schoolteacher born in 1948, was first seen in April, 1968. She reported that nine months earlier her hands and legs had become tremulous. In addition she had quick, purposeless, involuntary movements of her hands in response to being startled or while attempting to perform a voluntary act. She had trouble writing on the blackboard as the chalk would fly out of her hands and she would drop things.

Physical examination revealed a somewhat euphoric young woman with intention tremor of all four limbs and of her head. This was fine, fast, and constant when unsupported and disappeared when she was supine. Voluntary movements were interrupted by quick, shocklike, whole limb jerks, her tendon reflexes were explosive, plantar responses were down and she had no sensory signs or nystagmus. Her intelligence seemed normal. Investigations revealed an I.Q. of 110 , normal blood count apart from a hemoglobin of 10 grams and a sedimentation rate between forty and sixty millimeters in one hour Investigation for heavy metal intoxication, liver biopsy, spinal fluid and pneumoencephalogram were all normal. Plasma protein examination showed diminished albumin and a slightly elevated alpha globulin and a decrease in gamma globulin. Liver function studies were normal. Her EEG was abnormal with a diffuse increase in slow activity and bilateral random and synchronous complex activity The latter was provoked by eye opening and photic stimulation. Eighteen months after the onset of symptoms she had her first generalized epileptic seizure and was started on diphenylhydantoin and phenobarbital. This produced a marked improvement in her involuntary movements, but both drugs had to be discontinued after one month because of a drug reaction. Six months after this her urinalysis became positive for protein. Quantitative urinalysis revealed a proteinuria of five grams per day. Her creatinine clearance was abnormal. A renal biopsy showed a focal glomerulonephritis.

Her family history revealed that her mother was a chronic simple schizophrenic and had been in and out of mental hospitals for several years and a maternal aunt had hanged herself at age thirty-five.

About one year after the onset of her disease her speech became abnormal. It was slurred and her articulation was sloppy and in addition involuntary movements of her chest or diaphragm would interrupt her speech. At the same time her gait became ataxic.

In April 1970, she was seen in the Mayo Clinic. Investigations there revealed a hemoglobin of 13 grams and a normal red count and differential white count. Serum calcium was 9.3 milligrams percent, potassium $4.4 \mathrm{mEq}$. $/ \mathrm{L}$, serum sodium $141 \mathrm{mEq}$./L, plasma cholesterol 331 milligrams percent, protein bound iodine 5.4 micrograms percent and serum creatinine 1.35 milligrams percent. Serum enzymes were normal and serum protein electrophoresis showed decreased albumin at 2.68 grams percent and slightly increased alpha 2-globulin at 0.93 grams percent. Plasma lipoprotein showed no abnormalities. L.E. clot test was negative and sedimentation rate was 46 millimeters per hour. Serum ceruloplasmin was 46.1 milligrams percent and serum uric acid 8.0 milligrams percent. Urinalysis showed 3 plus protein, 3 white cells and occasional hyalin, granular and fatty casts.

By August 1970 she was worse. She was having major convulsions every month or six weeks, the involuntary movements were worse, her walking and handwriting and speech were deteriorating. She was readmitted and found to have massive proteinuria. Gamma globulin was decreased in her serum and her cerebrospinal fluid showed significant amounts of beta-globulin and immune electrophoresis showed a decrease of 
gamma A. Antinuclear factors were positive though L.E. cells were negative in her peripheral blood. Kidney biopsy revealed focal sclerosing glomerulonephritis. Viral studies on her blood revealed a cytomegalovirus titre in a strength of $1: 28$. This titre persisted on subsequent studies. Saliva immune electrophoresis showed decrease of gamma A globulin.

In September 1970, she had a repeat right renal biopsy with immunofluorescence studies and these were reported as showing immune damage to the basement membrane with a rather smooth pattern. B1 complement was also present in a vessel suggesting immune damage to vessels as well.

In November 1970, she received a short course of cyclophosphamide with no response. In December 1970, she was started on cytosine arabinoside in a dose of 20 mgms./sq. m/day. This was repeated on three occasions at weekly intervals with no change in her condition.

In March 1971, a needle biopsy of the brain was done and the report on this tissue is discussed below

In May 1971, her blood pressure was $130 / 90$, her sedimentation rate 108 millimeters per hour, hemoglobin 10 grams, and there was a large amount of protein in the urine.

In February, 1972 an EEG showed frequent distorted spikes, multiple runs of spike activity and spike and wave complex activity with a background of diffuse slow wave forms. The abnormalities were present with the patient blindfolded but were often aggravated by eye opening. Photic stimulation again produced high amplitude bilateral complex activity.

In February, 1973 she was admitted with a blood pressure of 190/110, shortness of breath, wild myoclonic involuntary movements, euphoria and marked dementia. She had many peripheral bruises, greatly reduced urine output and died.

In the last year of her life she had insisted on wearing two pairs of dark glasses and refused to have the blinds up. Any light provoked myoclonic jerks and she was quite certain that if these became frequent enough and coarse enough they always resulted in a generalized seizure. She was similarly made worse by loud noises and attempts at voluntary movement but not to the same extent as from bright light.

\section{Post-mortem Examination}

General autopsy findings: Numerous flat pigmented nevi were present over the neck, upper arms and legs. There was extensive anasarca. The right and the left lungs weighed 780 grams and 640 grams respectively and both displayed uremic changes. There was left ventricular hypertrophy. There was no excess of lipochrome in the cardiac muscle fibers. The liver was enlarged and weighed 2,000 gms. The capsule was smooth and the cut surface showed a normal lobular pattern.

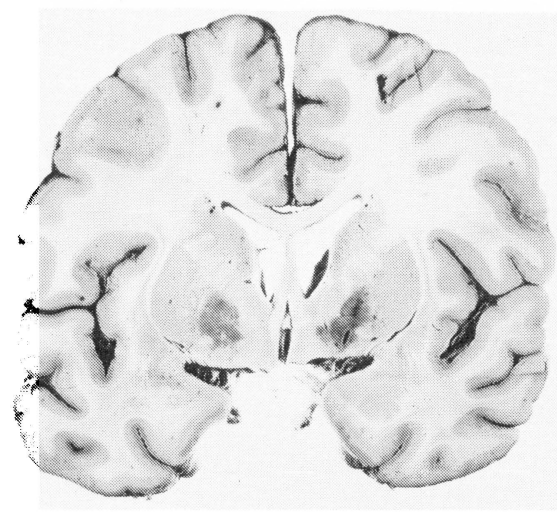

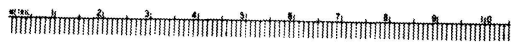

Figure 1-Coronal section of the brain showing symmetrical dark discoloration of the globus pallidus.

There was some indication that the liver was darker than normal. However, light microscopy failed to show changes in the hepatocytes. The kidneys were shrunken, the left weighed 70 grams and the right 90 grams. The glomeruli were mostly hyalinized. The tubules were atrophic. There was no lipid material and no intranuclear inclusions of cytomegalia in the surviving tubules. Gross brain findings: The wet brain weighed 1,300 grams. The leptomeninges and the peeled cortical surface were yellowish brown in color. There was no obvious gyral atrophy. The vessels were smooth and the circle of Willis complete. The optic nerves and the other cranial nerves were not remarkable. In coronal sections, the cortical ribbon was well preserved and the centrum semiovale was not attenuated. A track of the previous brain biopsy procedure extended from the lateral aspect of the right caudate nucleus to the pallidum. The pallidal nuclei were strikingly dark brown in color (Fig. 1) and so was the zona reticulata of the substantia nigra. The other subcortical nuclei were not remarkable. The cerebellum was not atrophic. The spinal cord was normal.

\section{Material and Methods:}

Blocks from various regions of the brain that was fixed in $10 \%$ formalin, were embedded in paraffin and after sectioning were stained with Hematoxylin-Eosin, Luxol-fast blue, PAS with and without diastase, phosphotungstic acid hematoxylin, Bodian's silver method, cresyl violet, Ziehl-Neelsen, Schmorl stain, Prussian blue method for demonstration of iron and Sudan black. Selected unstained sections and others which were treated with hydrogen peroxide $\left(\mathrm{H}_{2} \mathrm{O}_{2}\right)$ up to 12 hours were examined for autofluorescence.

For electron microscopy the brain, liver and muscle biopsies which were obtained 2 years before the patient's demise and which were embedded in methacrylate were reexamined. Fresh tissues from cerebral cortex and cerebellum were obtained 3 hours after the patient's death, and were fixed in $4 \%$ glutaraldehyde. Sections from basal ganglia fixed in formalin were post

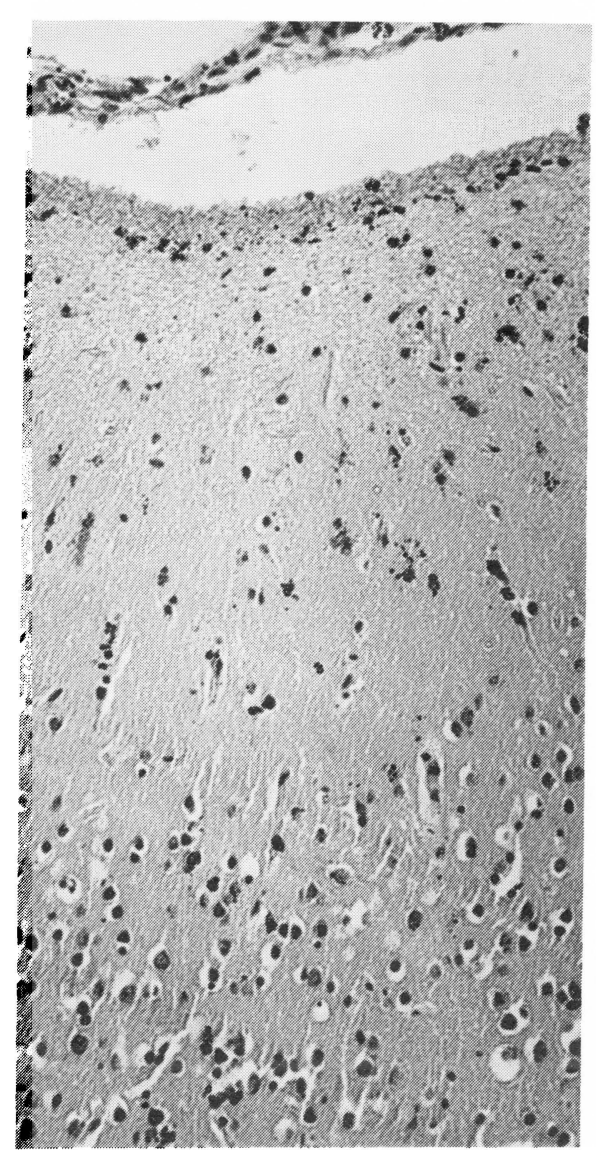

Figure 2 - Section from temporal lobe.

The leptomeninges contain pigmented cells. The superficial layers of the cortex contain fine and coarse granular pigment. The glial cells are outlined due to their content of pigment (H\&E X 100). 
fixed in $4 \%$ glutaraldehyde. These tissues were processed for SPURR embedding.

\section{Light Microscopic Findings:}

The leptomeninges contained considerable number of brown pigmented cells. Subpial gliosis was striking and was most intense at the depth of the sulci. Many of the glial processes in this region were well outlined because of their content of fine granular yellow-brown pigment. In addition to this fine pigment, coarser irregular granules, distributed in the outer two layers of the cortex were present (Fig. 2). Some of these had coalesced into particles up to 8-10 $\mu$ in diameter. The coarse pigment granules were brown and had a greenish refractile hue in $\mathrm{H} \& \mathrm{E}$ preparation. Some appeared free in the neuropil, others were contained within macrophages or pericytes and a few were in the vicinity of neurons or astrocytes. There was no selective lobar distribution for either the

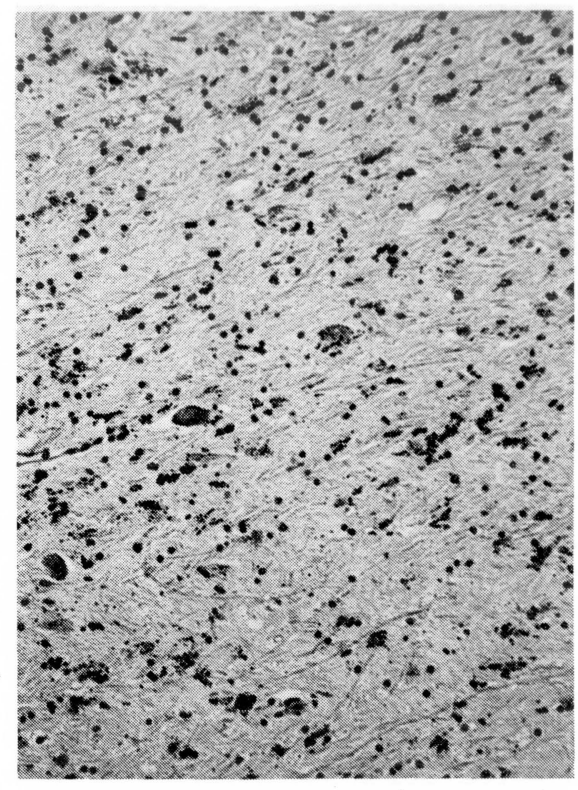

Figure 3 - The globus pallidus contains intracellular and extracellular pigment. (H\&E X 100).

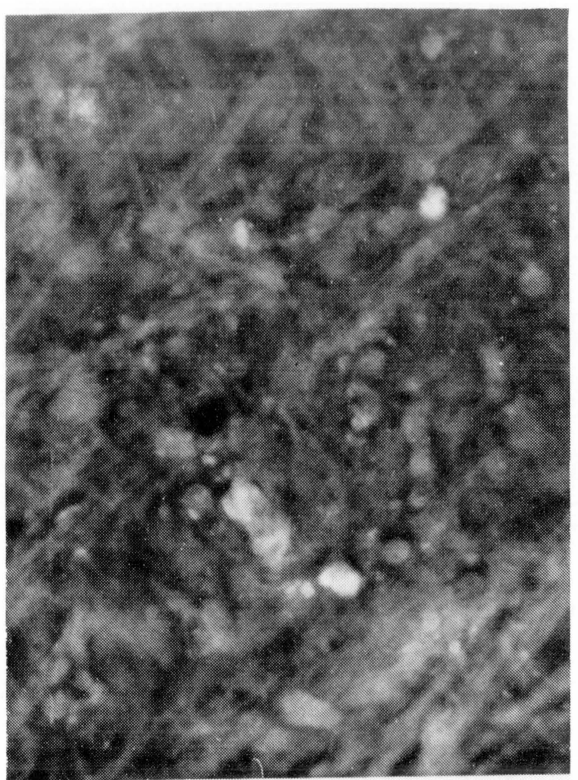

Figure 4 - Both pigments showed autofluorescence, the intracellular being more bright. Globus pallidus (X400).

TABLE I

Comparison between normal lipofuscin and neuromelanin, the I.N.P. and E.N.P. in Seitelberger and Simma case (1962) and the present case

\begin{tabular}{|c|c|c|c|c|c|c|}
\hline \multirow[b]{3}{*}{$\mathrm{H} \& \mathrm{E}$} & \multicolumn{2}{|c|}{ Normal brain } & \multicolumn{2}{|c|}{ Seitelberger and Simma } & \multicolumn{2}{|c|}{ Case under discussion } \\
\hline & Lipofuscin & Neuromelanin & I.N.P. & E.N.P. & I.N.P. & E.N.P. \\
\hline & yellow brown & dark brown & yellow gray & yellow brown & yellow brown & yellow brown \\
\hline Autofluorescence & + & - & + yellow & + bright yellow & $\begin{array}{c}+ \text { bright lemon } \\
\text { yellow }\end{array}$ & + dusky pumpkin \\
\hline $\mathrm{ZN}$ & + & - & + & + & + & \pm \\
\hline PAS & + & - & + & + & + & \pm \\
\hline LFB & + & - & & & + & greenish blue \\
\hline Nile blue & blue & brown & $+(\mathrm{F})$ & $+(\mathrm{F})$ & blue & - \\
\hline Prussian blue & - & - & - & \pm & - & - \\
\hline Sudan black & + & - & black & black & black & yellowish green \\
\hline Fontana & - & \pm & & + & & \\
\hline Schmorl's & + & + & & & \pm & \pm \\
\hline Bleaching with $\mathrm{H}_{2} \mathrm{O}_{2}$ & not bleached & bleached & & & not bleached & not bleached \\
\hline Ferrous $\mathrm{Fe}$ uptake & & & - & $\stackrel{ \pm}{=}$ & - & - \\
\hline
\end{tabular}


fine or coarse pigments. Similar pigments were also present in the pallidal nuclei and the zona reticulata of the substantia nigra (Fig. 3 ). The pigment was also present in smaller amounts in the choroid plexus. The histochemical properties of both pigments, that is, the intra- and extra-neuronal are compared in Table I. Both displayed autofluorescence (Fig. 4). There were no swollen axons or 'spheroids' associated with the excess extra-neuronal pigment. There was no neuronal cell loss in the cerebral cortex and the cytoarchitectonics were preserved. Only a few cortical neurons appeared to contain slight excess of light brown pigment and the cortical neurons were not ballooned or distended with storage material. However, in the thalamus and subthalamus the neuronal perikarya of some neurons disclosed excessive accumulation of PAS positive granules. These varied in size from dust-like particles to very coarse. They were not digested by diastase.

Neurons which normally accumulate lipofuscin early in life such as in the lateral geniculate, inferior olivary, and dentate nuclei showed simple neuronal atrophy. The optic nerves exhibited a few vacuoles.

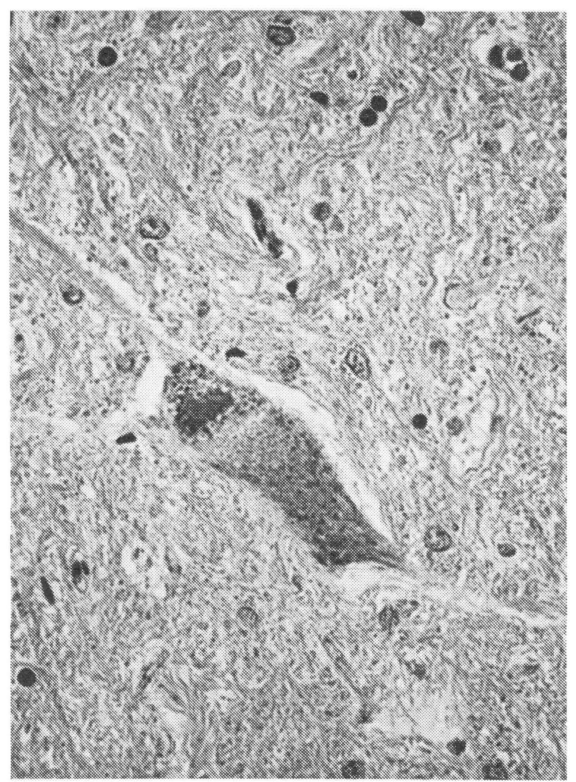

Figure 5 - Anterior horn cell in the lumbrosacral segment displaying Lafora bodies of the protein type. (H\&E X 250).
In the cerebellum, there was moderate Purkinje cell loss. The remaining cells had not accumulated any pigment. On the other hand, many Bergmann astrocytes and Golgi type II cells in the granular cell layer contained excess partially PAS positive fine and coarse golden brown pigment granules. The junctional zone was similarly sprinkled with these pigments.

In the spinal cord, no tract degeneration was observed. There was no obvious reduction in the number of the neurons despite the large accumulations of light brown pigments in the cytoplasm of some neurons. In the lumbosacral enlargement, Lafora bodies of the protein type (Fig. 5 ) and occasional degenerating enlarged neurites were observed.

\section{Ultrastructural Examination:}

Brain biopsy: Abnormal electron dense irregular cytoplasmic inclusions were present in some of the cortical neurons and occasionally in neuroglial profiles. The inclusions varied in size and shape. Very few were membrane bound. The more complex inclusions contained a few lamellae having a periodicity of $75 \AA$ and rarely the light globular component of lipofuscin (Fig. 6). There was no obvious axonal degeneration.

Autopsy material: Postmortem artefacts had rendered most ultrastructural details unrecognizable. The pigment material, however, was little altered and was structurally complex and variable in size and shape. The pigments were formed of dense amorphous masses embedded in a granular or finely beaded background. They almost always displayed small arrays of alternating electron dense and lucent bands of about $75 \AA$ (Fig. 7). They rarely contained the globular pale component of lipofuscin. A few of these pigment complexes attained considerable size, up to $10-12 \mu$ in diameter. They were partly or totally surrounded by a trilaminar unit membrane. Some of the abnormal pigments had a finger-print pattern (Fig. 9). Others were roughly polygonal or occurred in mulberry like clusters (Fig. 10). The latter appeared to correspond to what we have termed the extra- neuronal pigment by light microscopy. They were dense, usually lacked the beaded background and rarely exhibited lamellar arrays. However, both the intraneuronal and extracellular pigment had common features as illustrated in Fig. 11. Multilamellar cytoplasmic bodies (MCBs) like those seen in Tay Sach's disease were rarely encountered in neuronal perikarya (Fig. 12). In the anterior horn cells, the accumulated material bore a close resemblance to lipofuscin. They were all surrounded by a trilaminar unit membrane and often contained a pale lipid globule (Fig. 13). Rarely the inclusions were seen in axoplasm (Fig. 14). Occasional Hirano bodies were present in the cerebellum.

Liver biopsy: Most of the hepatocytes contained numerous abnormal electron dense cytosomes that were bound with a trilaminar membrane. They varied in size and shape, some were globular, others were conchoidal and a few bore some resemblance to the abnormal cytosomes of Niemann-Pick's disease.

Muscle biopsy: There were only a few lipofuscin pigments in the perinuclear zone but they were not exceptionally increased.

\section{DISCUSSION}

The patient, a 24 year old female who complained of progressive incapacitating myoclonic jerks over the past 7 years was diagnosed, on the basis of ultrastructural studies of her brain biopsy, to have ceroidlipofuscinosis. This term was first coined by Zeman and Dyken (1969) to encompass some of the nonglycolipid storage diseases of unknown and putative enzymatic deficiency. This diagnosis was verified at autopsy which also displayed excessive deposition of yellow-brown pigment in the nigropallida, outer layers of the cortex and leptomeninges. Although the pigmentation of the nigropallida superficially resembled Hallervorden-Spatz disease, the intracellular accumulation of abnormal cytosomes, the absence of siderocalcific deposits in the pallida and the lack of axonal spheroids made this diagnosis unlikely (Dowling et al., 1974). 


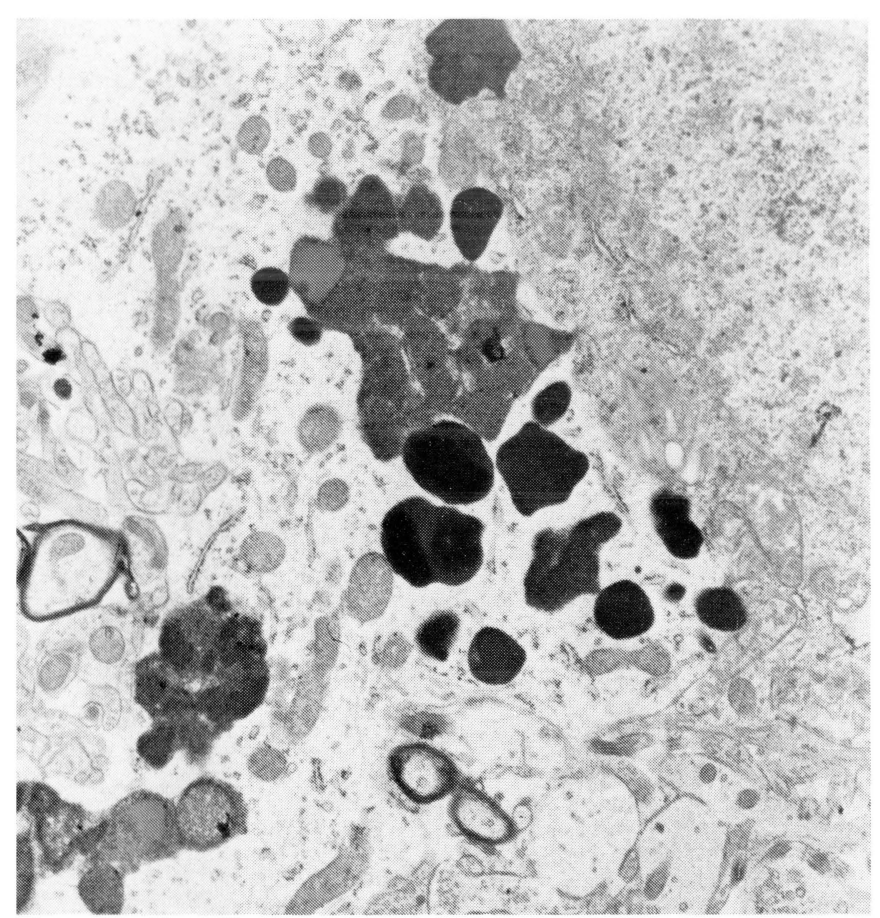

igure 6-Methacrylate embedded frontal lobe biopsy showing a neuronal perikaryon with numerous heterogenous dense profiles. The more complex one contains the light globular component of lipofuscin and a few lamellar arrays. A satellite oligodendroglion also contains an abnormal dense cytosome. (X22.610).

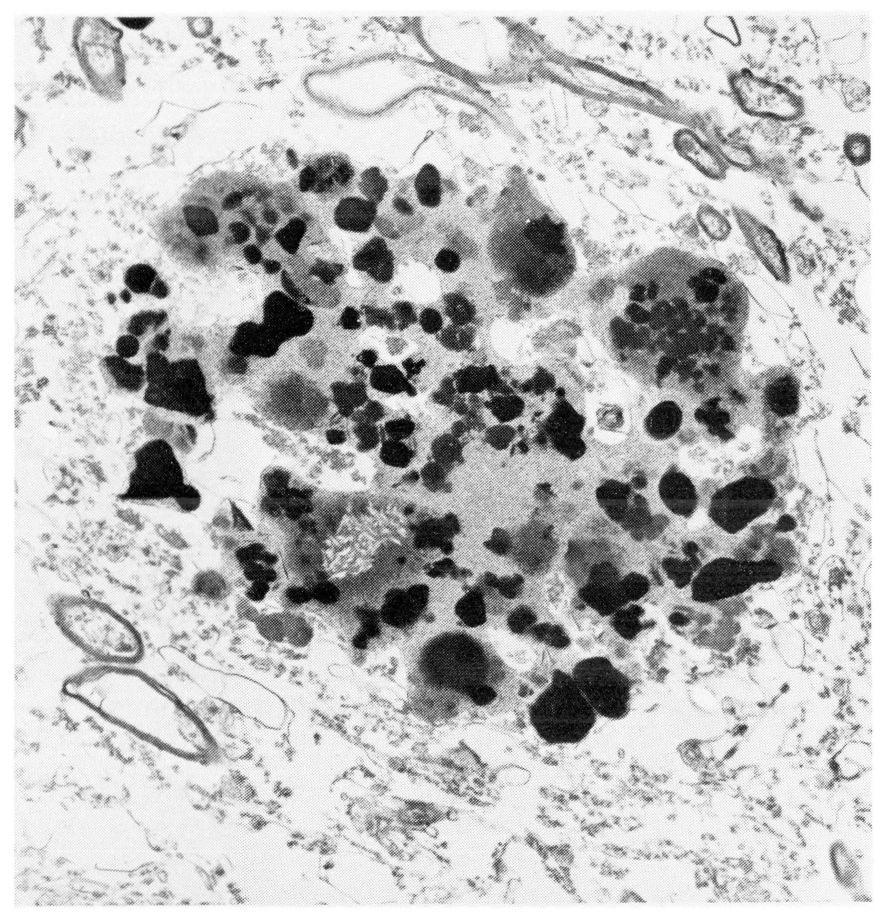

Figure $8-$ 'Extraneuronal pigment'. Some of these attained sizes up to $10-12 \mu$ Inner nucleus of the globus pallidus. (X15.890).

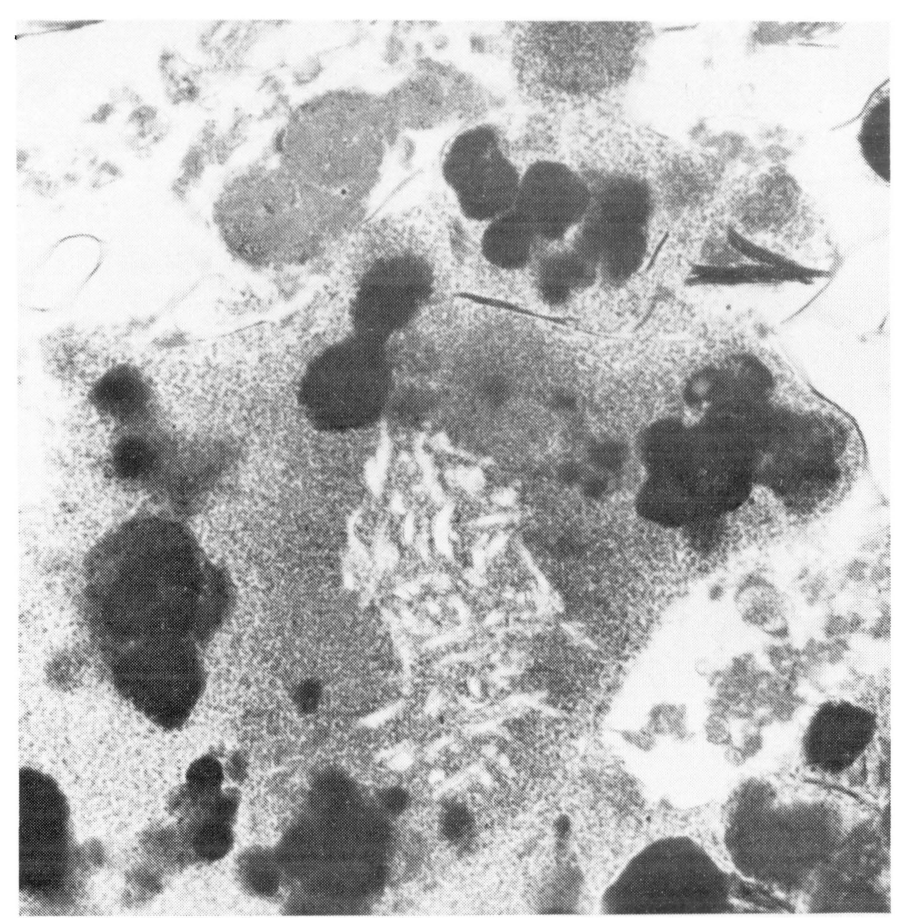

Figure 7 - Most of the abnormal inclusions consisted of dense amorphous 'blotches' superimposed on a beaded or granular background. A few lamellae were almost always present even in the ones that were very dense. (X 61.250).

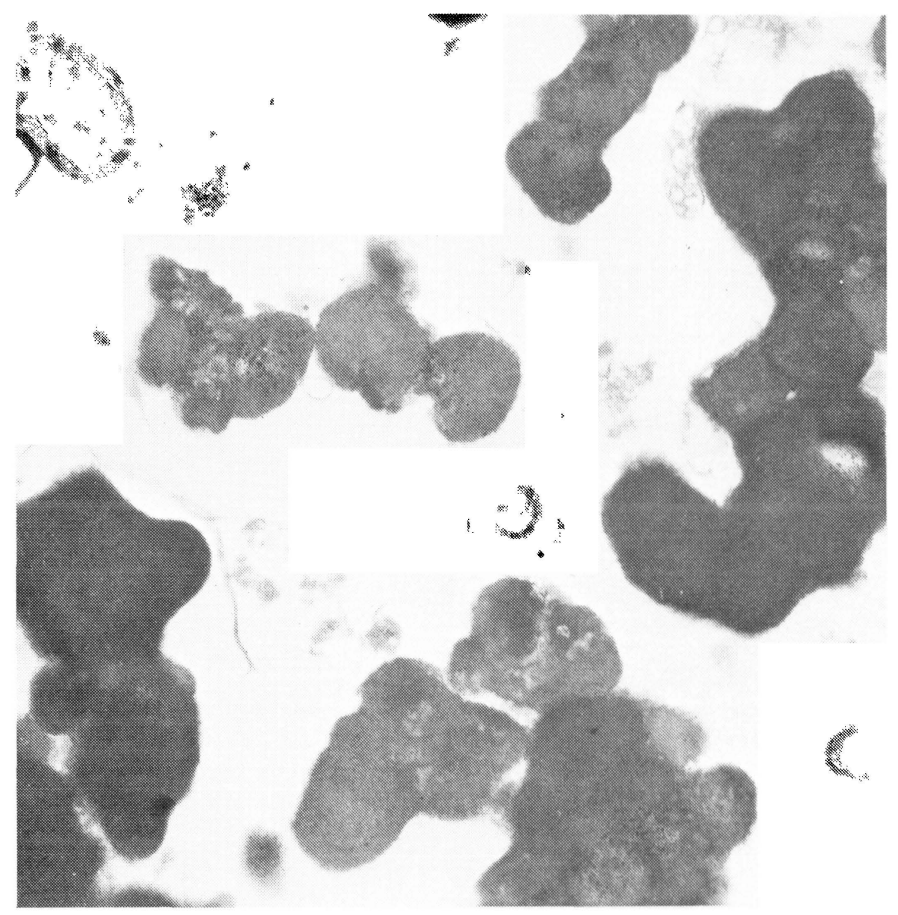

Figure 9 - A finger print pattern was uncommon. Putamen (X61.000). 


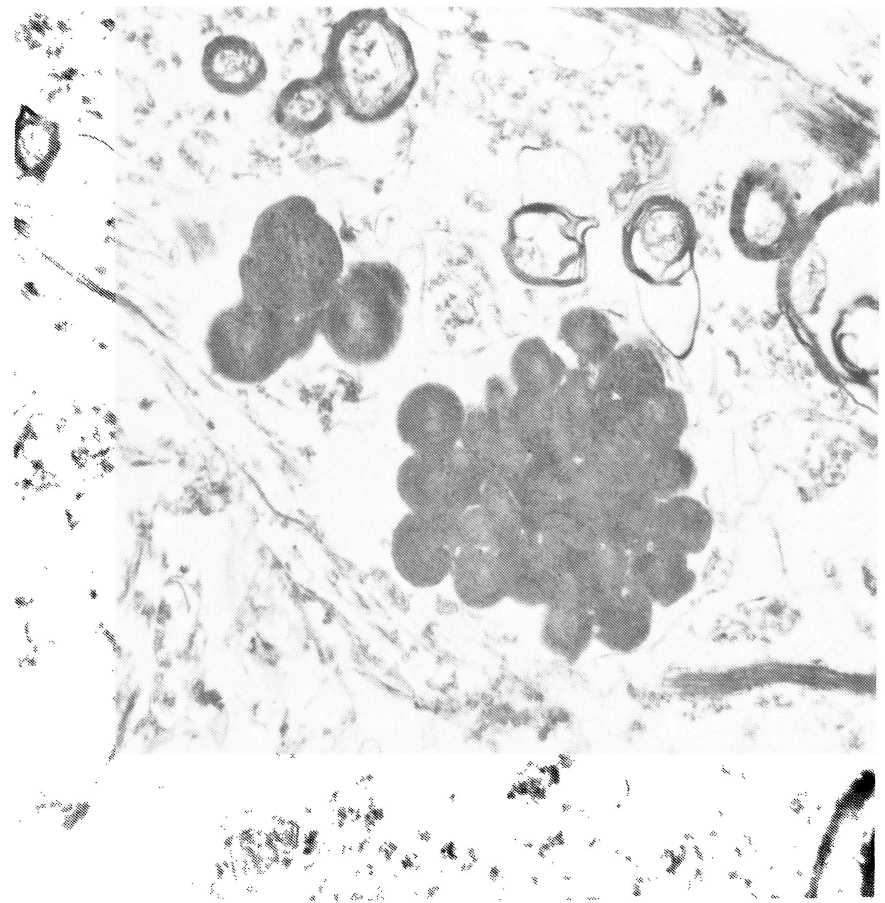

Figure 10 - 'Extraneuronal pigment' composed of dense globular fused masses (X29.750).

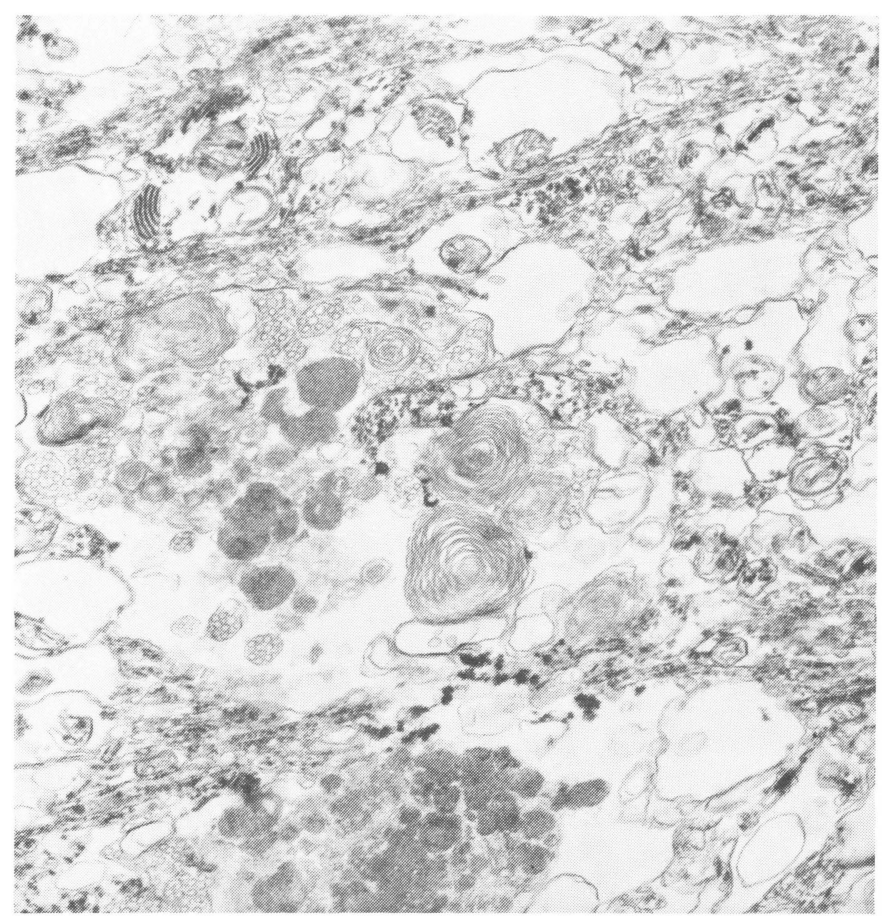

Figure 12 - Multilamellar cytoplasmic bodies (MCB) were rare. Cerebellum. Note striate bodies (artefact) (X22.610).

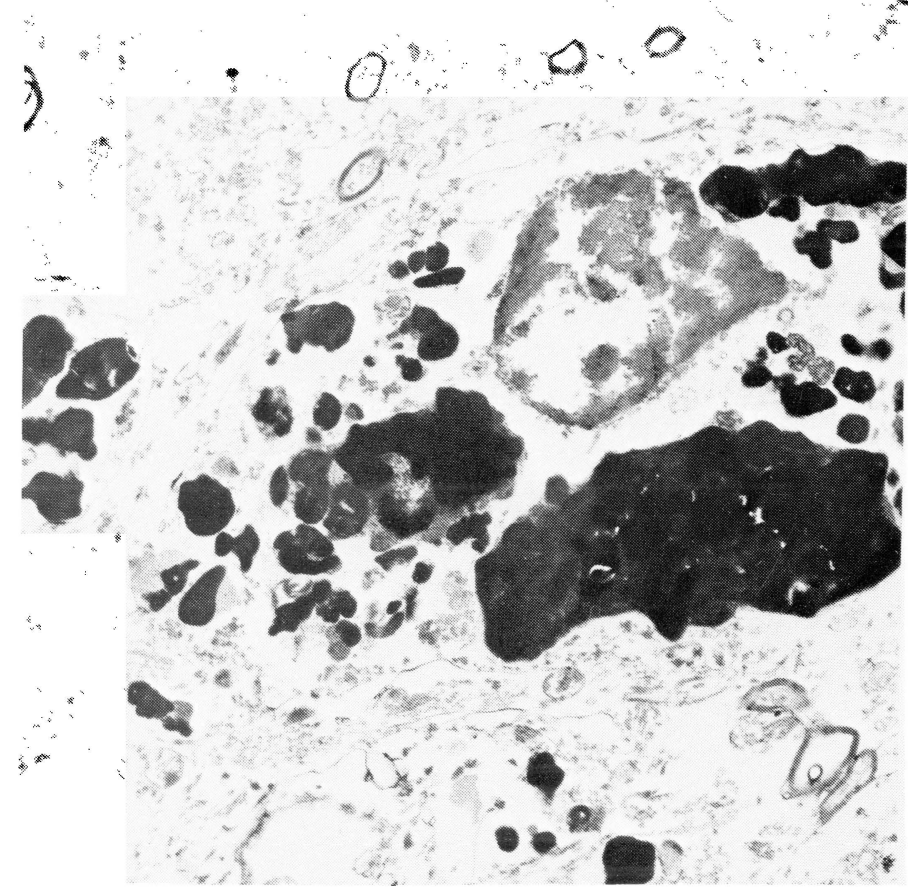

Figure 11 - A pallidal neuron containing complex cytosomes. The polygonal dense amorphous was more frequently strewn in the neuropil and the ones that have a beaded background were located more often in perikarya. (X15.890).

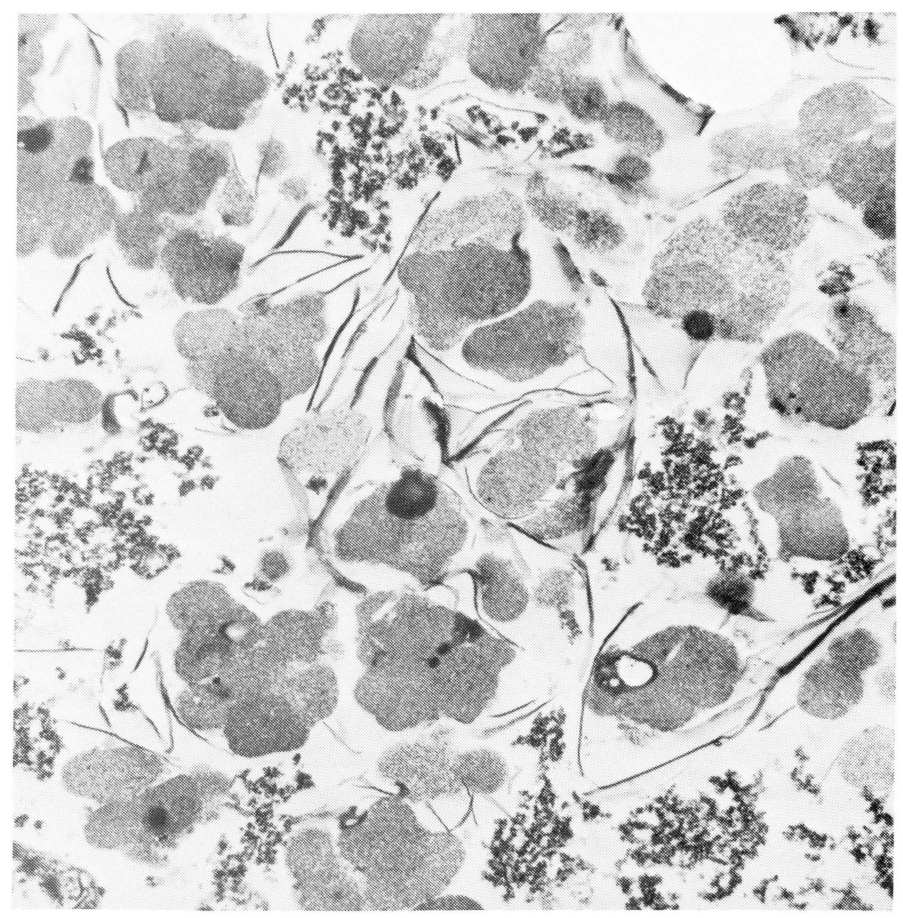

Figure 13 - Anterior horn cells filled with cytosomes resembling lipofuscin. (X29.750). 


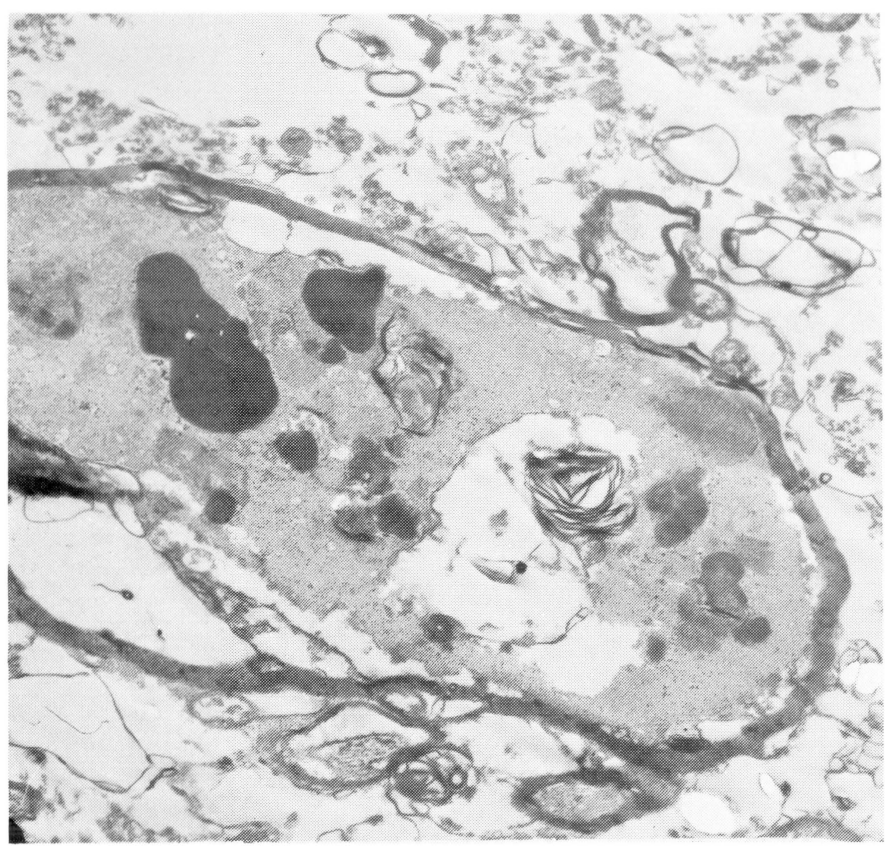

Figure 14 - Rarely the pigment was seen in axoplasm of myelinated fibers. Globus pallidus (X22.610).

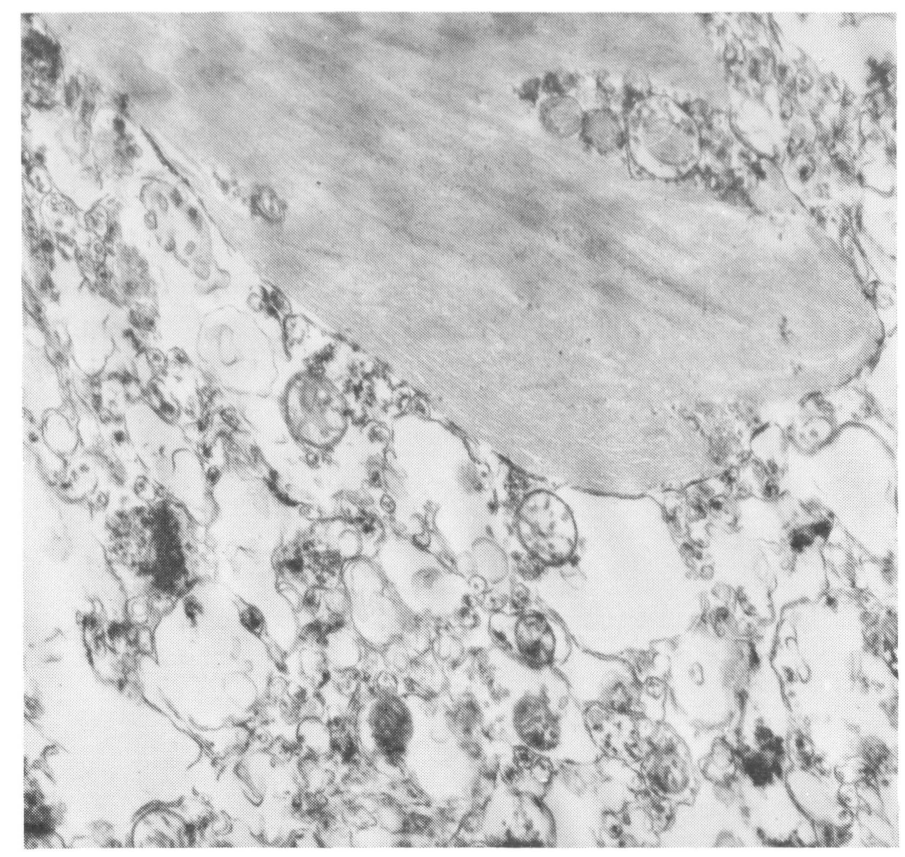

Figure 15 - A Hirano body in cerebellum. (X40.600).

TABLE II

Comparison between present case and all previously reported cases of pigment variant of Kufs' disease

\begin{tabular}{|c|c|c|c|c|c|c|c|c|}
\hline & Jervis, 1952 & \multicolumn{2}{|l|}{ Moschel, 1954} & $\begin{array}{l}\text { Zeman and } \\
\text { Scarpelli, } 1958\end{array}$ & $\begin{array}{l}\text { Simma, } 1957 \\
\text { Seitelberger \& } \\
\text { Simma, 1962 } \\
\end{array}$ & $\begin{array}{l}\text { Jakob and } \\
\text { Kolkmann, } 1973 \\
\end{array}$ & \multicolumn{2}{|l|}{ Present Case } \\
\hline Age of onset & $5 \mathrm{mo}$ & \multicolumn{2}{|l|}{$15 \mathrm{y}$} & $5 \mathrm{y}$ & $14 \mathrm{y}$ & $31 \mathrm{y}$ & \multicolumn{2}{|l|}{$17 \mathrm{y}$} \\
\hline Age at death & $11 \mathrm{y}$ & \multicolumn{2}{|l|}{$39 \mathrm{y}$} & $20 \mathrm{y}$ & $33 \mathrm{y}$ & $40 \mathrm{y}$ & \multicolumn{2}{|l|}{$24 \mathrm{y}$} \\
\hline Race & Jewish & \multicolumn{2}{|l|}{ Jewish } & & Jewish & & \multicolumn{2}{|l|}{ non-Jewish } \\
\hline $\begin{array}{l}\text { Pertinent clinical } \\
\text { findings }\end{array}$ & $\begin{array}{l}\text { psychomotor } \\
\text { retardation. } \\
\text { No involunt. mov. } \\
\text { Cherry red spot } \\
\text { Bilateral } \\
\quad \text { cataract \& } \\
\text { corneal opacities } \\
\end{array}$ & \multicolumn{2}{|c|}{$\begin{array}{l}\text { invol. mov. } \\
\text { speech disorder } \\
\text { mental } \\
\text { deterioration } \\
\text { spasticity }\end{array}$} & $\begin{array}{l}\text { psychomotor } \\
\text { deterioration } \\
\text { stiffness }\end{array}$ & $\begin{array}{l}\text { irritability } \\
\text { ataxia } \\
\text { stiffness } \\
\text { dementia } \\
\text { polymorphous } \\
\text { invol. mov. }\end{array}$ & $\begin{array}{l}\text { paranoid- } \\
\text { psychosis } \\
\text { progressive } \\
\text { dementia }\end{array}$ & \multicolumn{2}{|c|}{$\begin{array}{l}\text { invol. movements } \\
\text { speech difficulty } \\
\text { grand mal } \\
\text { seizures }\end{array}$} \\
\hline $\begin{array}{l}\text { Appearance of } \\
\text { storage material }\end{array}$ & $\begin{array}{l}\text { similar to } \\
\text { juvenile A.F.I. }\end{array}$ & $\begin{array}{l}\text { as in late } \\
\text { A.F.I. }\end{array}$ & & $\begin{array}{l}\text { 'ballooning' of } \\
\text { some neurons }\end{array}$ & $\begin{array}{l}\text { 'amaurotic nerve } \\
\text { cell alterations' }\end{array}$ & $\begin{array}{l}\text { similar to } \\
\text { late A.F.I. }\end{array}$ & \multicolumn{2}{|l|}{$\begin{array}{l}\text { no conspicuous } \\
\text { nerve cell } \\
\text { distension } \\
\end{array}$} \\
\hline $\begin{array}{l}\text { Distribution of } \\
\text { E.N.P. }\end{array}$ & $\begin{array}{l}\text { pallida } \\
\text { nigra } \\
\text { cer. \& cebl. } \\
\begin{array}{l}\text { cortex } \\
\text { leptomeninge }\end{array}\end{array}$ & $\begin{array}{l}\text { pallida } \\
\text { nigra } \\
\text { choroid } \\
\quad \text { plexus } \\
\text { cer. cortex } \\
\text { leptomeninges }\end{array}$ & $\begin{array}{l}++ \\
+H \\
+4 \\
+ \\
+\end{array}$ & $\begin{array}{l}\text { pallida, nigra } \\
\text { dentate, thalami } \\
\& \text { subthalamic } \\
\text { nuclei, } \\
\text { cer. cortex }\end{array}$ & $\begin{array}{l}\text { pallida } \\
\text { nigra } \\
\text { cer. \& cebl. } \\
\quad \text { cortex } \\
\text { leptomeninge }\end{array}$ & $\begin{array}{l}\text { pallida } \\
\text { nigra }\end{array}$ & $\begin{array}{l}\text { pallidum } \\
\text { nigra } \\
\text { cer. cortex } \\
\text { leptomeninges } \\
\text { cerebellum } \\
\quad \text { junctional } \\
\text { zone }\end{array}$ & $\begin{array}{l}+H \\
+H \\
+H \\
+H\end{array}$ \\
\hline Visceral involvement & & & & $\begin{array}{l}\text { hepatospleno- } \\
\text { megaly } \\
\text { (clinically) }\end{array}$ & & & $\begin{array}{l}\text { abnormal } \\
\text { lipopigment } \\
\text { in hepatocyt }\end{array}$ & anules \\
\hline
\end{tabular}

E.N.P.: extra-neuronal pigment Blank: data not available cebl.: cerebellum
AFI: amaurotic family idiocy 


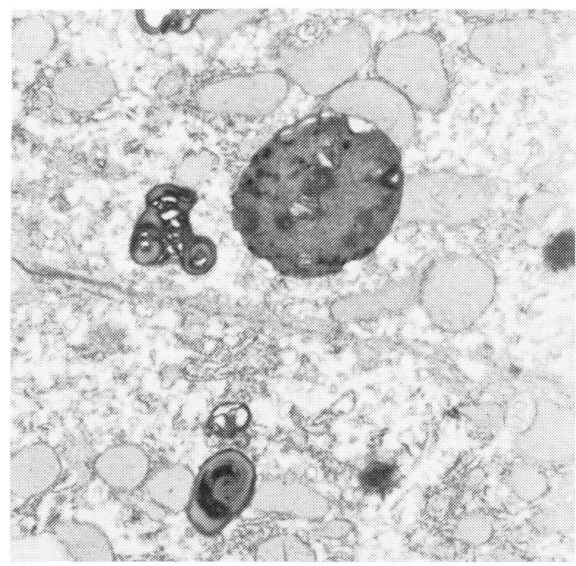

Figure 16 - Liver biopsy. The hepatocytes displayed pleomorphic abnormal cytosomes. (X29.750).

From the pathological point of view the conditions satisfied the criteria of pigment variant of Kufs' disease first described by Seitelberger and Simma in 1962. To our knowledge only one case has been added to the literature (Jakob and Kolkmann, 1973). The cases published (Jervis, 1952; Moschel, 1954; Simma, 1957; Zeman and Scarpelli, 1958) are tabulated for comparison (Table II).

Whether it is justifiable to separate nosologically this condition from the more common forms of Kufs' disease remains to be settled. Pigmentation of the nigropallida has been described in a variety of conditions and is considered to be nonspecific (Seitelberger, 1971). However, the pigment that accumulates in the neuropil in these conditions is rich in iron while in our case and most of the reported cases of pigment variant of Kufs' disease, the pigment did not react for iron. Also, nonspecific pigmentation of the nigropallida was never associated with accumulation of pigment in the cortical rind. The nature of the extraneuronal pigment is uncertain since this was never isolated and biochemically characterized. Some insight has been gained by histochemical techniques. However, the results are often at variance as is shown in Table I. The source of this pigment is even more mysterious. Its occurrence in the leptomeninges and its distribution over the surface of the cerebrum and cerebellum and to a lesser extent in the choroid plexus closely resembled the distribution of hemosiderin in cases of marginal siderosis (Koeppen and Barron, 1971) suggesting that the substance or its precursors may be in the CSF. The patient's CSF composition was normal. It was also suggested that the pigment may be derived from effete neurons that contained the abnormal cytosomes (Jakob and Kolkmann, 1973) but the amount of pigment accumulating in the neuropil was more than could be accounted for by the reduction in the number of neurons. However, ultrastructurally the extra-cellular pigment seemed to have the same basic composition as the intracellular pigment and both shared some common features with the storage material found in the adult form of ceroid lipofuscinosis (Zeman et al., 1970). The most frequently encountered inclusion had a dense homogeneous central patch superimposed on a beaded background that occasionally contained lamellar arrays. They resembled the granular osmiophilic deposits (GROD) described by Carpenter et al. (1973). Denser and more homogeneous bodies were more frequent in the cortex. Definite fingerprint pattern was uncommon and so were the curvilinear profiles and membranous cytoplasmic bodies (MCB). Inclusions resembling lipofuscin, although present in pallidal cells, were more numerous in the anterior horn cells. The heterogeneity of the pigment has been observed by other authors especially in the juvenile and adult forms of ceroid lipofuscinosis (Chou and Thompson, 1970; Dekaban and Herman, 1974). Some of the authors suggested that the various inclusions seen in these nonglycolipid neuronal storage disorders might represent different steps in the evolution of a single process of lipid peroxidation toward the formation of an abnormal insoluble residue, ceroid (Zeman, 1974). We might add that local factors in different regions of the neuraxis and for that matter in different organs might also contribute to the variation in the appearance and composition of these inclusions.
This was also suggested by Park et al. (1975) in Hallvervorden-Spatz syndrome to explain the histochemical discrepancies of the pigment in the various conditions that constitute the syndrome.

The finding of lipid inclusions in hepatocytes confirm previous observations that the condition is a systemic disorder and may involve other viscera (Kornfeld 1972). However, there are very few cases on record where the hepatocytes were definitely involved in Kufs' disease. Bignami et al (1969) reported typical lipofuscin bodies in hepatic and splenic macrophages but did not illustrate them. Carpenter et al (1973) found them in abundance in skeletal muscles, but rarely in the hepatocytes. This was the reverse of what we observed in our case. Interestingly some of the inclusions in the hepatocytes resembled the cytosomes described in Niemann Pick's disease (Lejeune et al. 1973). This further strengthened the notion that the inclusions contain among other things sphingolipids and that the ambiant environment influences the morphology of the inclusions.

Clinically it was interesting to note that the patient was able to complete the University of Manitoba, Teacher's course and her mentation was not seriously hampered during the early course of her disease. There was some tenuous and circumstantial evidence that the condition might have been hereditary since the mother was under psychiatric treatment and a maternal aunt hanged herself at the age of 35 . In this respect ceroid lipofuscinosis has often presented with psychiatric problems as indicated in Table II and both forms of autosomal inheritance have been described in this condition. There are other case reports of mental disease in the family members of patients with proven ceroid lipofuscinosis (Kornfield, 1972; Pallis et al., 1967). In the autosomal dominant form Boehme et al. (1971) have found a consistent homotypic and homochronic pattern.

\section{REFERENCES}

BIGNAMI, A., PALLADINI, G. and BORRI, P (1969). Neuronal Lipidosis with 
visceral involvement in an adult. Acta Neuropath. (Berl.) 12, 52-61.

BOEHME, D. H., COTTRELL, J C., LEONBERG, S. C. and ZEMAN, W. (1971). A dominant form of neuronal ceroid-lipofuscinosis. Brain, 94, 745-60.

CHOU, S. M. and THOMASON, H. G. (1970). Electron microscopy of storage cytosomes in Kufs' disease. Arch. Neurol., 23, 489-501.

DEKABAN, A. S. and HERMAN, M. H. (1974). Childhood, juvenile and adult cerebral lipidoses. Are there different nosological entities? Arch. Pathol., 97, 65-73.

DOWLING, E. C., SCHOENE, W C. and RICHARDSON, E. P (1974). Hallervorden-Spatz syndrome. Arch. Neurol., 30, 70-83.

JACOB, $H$ and KOLKMANN, F.-W.-(1973). Zur Pigmentvariante der adulten form der amaurotischen Idiotie (Kufs). Acta Neuropath. (Berl.), 26, 225-36.

JERVIS, G. A. (1952). Hallervorden-Spatz disease associated with atypical amaurotic idiocy J Neuropath. exp. Neurol. 11: 4-17.

JERVIS, G. A. (1970). Rare or nosologically obscure neurolipidoses. Handbook of Clin- ical Neurology, Vol. 10. P J. Vinken and G. W Bruyn, eds. North-Holland Publishing Company, Amsterdam. pp. 550.

KOEPPEN, A. H. W and BARRON, K. D. (1971). Superficial siderosis of the central nervous system. A histological, histochemical and chemical study. J. Neuropath. Exp. Neurol., 30, 448-69.

KORNFELD, M. (1972). Generalized lipofuscinosis (Generalized Kufs disease). J. Neuropath. Exp. Neurol. 31, 668-81.

LEJEUNE, F., ALLAIN, J. P., LE COQ, D. and TURPIN, F (1973). La cellule de Niemann-Pick, aspects en cytologie optique et ultrastructurale. Path.-Biol., 21, 483-96.

MOSCHEL, R. (1954). Amaurotische Idiotie mit einer besonderen Form von Pigmentablagerung. Dtsch. Z. Nervenheilk. 172: 102-110.

PALLIS, C. A., DUCKETT, S., PEARSE, A. G. E., (1967). Diffuse Lipofuscinosis of the Central Nervous System. Neurology: 17, 381-394.

PARK, B. E., NETSKY, M. G. and BETSILL, W. L., JR. (1975). Pathogenesis of pigment and spheroid formation in Hallervorden-Spatz syndrome and related disorders. $25,1172-8$.
SEITELBERGER, $F$ and SIMMA, K. (1962). On the pigment variant of amaurotic idiocy Cerebral sphingolipidoses. S. M. Aronson and B. W Volk, eds. McGrawHill, New York, pp. 1324-8.

SIMMA, K. (1957). Zum Verlauf der Hallervorden-Spatzschen Krankheit. Psychiat. Neurol. (Basal), 133, 39-46.

ZEMAN, W and D. G. SCARPELLI (1958). The non-specific lesions of HallervordenSpatz disease. J. Neuropath. exp. Neurol. 17:622-630.

ZEMAN, W and DYKEN, P. (1969). Neuronal ceroid-lipofuscinosis (Batten's disease). Relationship to amaurotic familial idiocy? Pediatrics, 44, 570-83.

ZEMAN, W, DONAHUE, S., DYKEN, P., and GREEN, J. (1970). The neuronal ceroid-lipofuscinoses (Batten-VogtSyndrome). Handbook of Clinical Neurology. P J Vinken and G. W. Gruyn, eds. North-Holland Publishing Company, Amsterdam. pp. 588-679.

ZEMAN, W. (1974). Presidential Address: Studies in neuronal ceroid-lipofuscinosis. J. Neuropath. Ezp. Neurol., 33, 1-12.

\section{WANTED}

\section{Back Numbers of \\ Canadian Journal of \\ Neurological Sciences}

Vol. 1 - 1974

Will pay $\$ 5.00$ each

Please Mail to

1516 - 233 Kennedy Street

Winnipeg, Canada

R3C 3J5 